\title{
Bunch Yield of 'Grand Naine' (AAA) Banana as Influenced by the Varied Components of Precision Farming Systems
}

\author{
Utpal Das*, R.K. Bhattacharyya and K. Baruah \\ Assam Agricultural University, Jorhat 785 013, Assam, India \\ *Corresponding author
}

\section{A B S T R A C T}

\begin{abstract}
'Grand Naine' is superior selection of Giant Cavendish. The horticultural nomenclature of this cultivar is Musa acuminata (AAA). It is a high yielding Cavendish variety introduced to India from Isreal. This banana cultivar has recently been introduced in Assam from tropical parts of India for commercial cultivation. However, its suitability and ameliorative measures are yet to be ascertained under agro-climatic conditions of Assam. Banana is a heavy feeder of nutrients and as a mesophytic plant it requires high soil moisture for good growth and development leading to production of a heavy bunch. Drip fertigation results in high water use efficiency, uniformity of plant, reduced application cost for fertilizers, reduced labour demand, and reduced weed infestation, control erosion, reduced salinity hazards and more crop productivity per unit area. The present study was programmed in 2014-15 to evaluate the efficacy of the varied components of precision farming systems comprising drip irrigation ( $80 \% \mathrm{ER}$ ), fertigation ( $75 \% \mathrm{RDF}$ ), micronutrient foliar spray (Commercial formulation 'Tracel'2\%), bunch spray of sulphate of potash (2\%) as well as black LDPE film $(50 \mu)$ mulch over the traditional system of soil nutrient application $(110 \mathrm{~g}$ $\mathrm{N}, 33 \mathrm{~g} \mathrm{P}_{2} \mathrm{O}_{5}$ and $330 \mathrm{~g} \mathrm{k}_{2} \mathrm{O}$ ) and flood irrigation (15 day intervals) in 'Grand Naine' banana. Components of precision farming significantly increased bunch yield. The highest bunch weight $(21.68 \mathrm{~kg})$ as well as highest yield (66.91t/ha) were recorded in all combinations of precision farming components with drip-fertigation. Micronutrient foliar spray, bunch spray with potassium and black LDPE film mulch. Computation of Harvest Index reveals highest Harvest Index of $32 \%$ in all combinations of precision farming components as against the lowest of $30 \%$ in traditional system of banana culture depicting the superiority of the precision farming system over the latter.
\end{abstract}

\section{Introduction}

Precision farming is a farming management concept based on observing, measuring and responding to inter and intra-field variability in crops. Crop variability typically has both a spatial and temporal component which makes statistical/ computational treatments quite involved. It involves the application of technologies and principles to manage spatial and temporal variability associated with all the aspects of agricultural production for improving crop performance and environmental qualities. In short it means adding the right amount of treatment at the right time and the right location within a field. Philosophy behind the precision farming is that production inputs (seed, fertilizer, 
chemicals etc.) should be applied as needed and where needed for the economic production.

Grand Naine bananas have a shelf life which is much longer than the Robusta. Long cylindrical fruits with less curvature attractive yellowish green color at maturity, internationally acceptable both as fresh fruit and in processed form. Pulp-peel ratio is more and highly suitable for processing.

Water is one of the most important factors limiting production of banana crop. Banana is more sensitive to moisture stress than any other fruit crops. Banana requires sufficient soil moisture throughout its growth period. Lack of water can lead to declining plant health, lower yield and poor quality of fruits. In fact, every aspect of plant growth is affected by water stress. However, frequent water stress may upset the nutrient status of the plants, resulting in various nutrient deficiencies and metabolic disturbances. Irrigation is the only means to supply water to the crops during these critical stages. Among various methods of irrigation, drip irrigation is the best available technology for judicious use of water for growing horticultural crops in large scale on sustainable basis (Hasan and Sirohi, 2006).

Banana is a heavy feeder of nutrients and requires large quantities of nutrients for its growth, development and yield. For higher yield and quality of banana, application of adequate nutrients is of prime importance. Application of fertilizer along with irrigation water is fairly a new technology. It offers the best solution for intensive and economical crop production, where both water and fertilizers are delivered to growing of crop through drip irrigation system. It helps in increasing nutrient use efficiency and provides essential elements directly to the active root zone thus minimizing losses of expensive nutrients which ultimately helps in improving productivity and quality of fruit crops. Drip cum fertigation or drip fertigation technology, in addition to resulting high water use efficiency, encompasses the application of solid or liquid mineral fertilizers through drip system, thus supplying nutrient containing irrigation water to the crops.

The climate and soil condition of Assam and its neighboring states are ideal for commercial cultivation of banana, but the productivity is low as compared to all India level. This low productivity may be ascribed to several factors such as unsystematic and improper methods of cultivation, attack of pests and diseases and non-application of manures and fertilizers etc. Among these factor non-fertilization or inadequate fertilizer application is the chief cause. Studies have proved that besides fertilizer, the micronutrients like copper $(\mathrm{Cu})$, zinc ( $\mathrm{Zn}$ ), molybdenum (Mo), boron (B), and manganese (Mn) are also necessary for optimum vegetative growth, fruit yield and quality of banana (Srivastava, 1964).

The post shooting application of Sulphate of Potash twice resulted in increase in bunch weight, finger weight, finger length, pulp weight and peel weight; pulp to peel ratio, total bunch yield and benefit: cost ratio (Mulagund et al., 2015).

Mulching is practiced to reduce the evaporation component of the crop water requirement. During the earlier stages of crop growth period, evaporation is the major component, while under well-developed canopy, transpiration is much higher than evaporation.

\section{Materials and Methods}

Using Banana Cv. Grand Naine, the field experiment was conducted at the Experimental Farm, Department of Horticulture, Assam 
Agricultural University, Jorhat during the year 2014-2015. The experiment was laid out in Randomized Block Design (RBD) with four replication comprising five treatments. There were twenty plots each having nine plants with spacing of $1.8 \mathrm{~m} \times 1.8 \mathrm{~m}$.

The treatments and treatment combination used in the experiment are as follows:

$\mathrm{T}_{1}$ : drip irrigation+ fertigation+ micronutrient foliar spray + bunch spray of SOP + Black polyethylene mulching

$\mathrm{T}_{2}$ : drip irrigation+ fertigation + micronutrient foliar spray + bunch spray of SOP

$\mathrm{T}_{3}$ : drip irrigation+ fertigation + micronutrient foliar spray

$\mathrm{T}_{4}$ : drip irrigation + fertigation + bunch spray of SOP

$\mathrm{T}_{5}$ : soil application of region specific $\mathrm{RDF}+$ flood irrigation (control)

\section{Layout of drip lines}

A drip irrigation system was installed at the experimental site as per layout shown in Fig 3.3. From the main line, sub main line was connected and laterals were fitted in each row of the plant through sub main. Single dripper was used to irrigate each plant. LLDPE (linear low density polyethylene) pipes of $12 \mathrm{~mm}$ diameter in size were used as lateral where pressure compensating type. Prior to installation, test runs were carried out to verify the design discharge rating of the dripper.

The time interval in between to drip irrigation is done by observing metrological parameters. The quantity of water applied through drip irrigation at $80 \%$ ER was $208.80 \mathrm{~cm}$. There were 21 irrigations through drip. In each irrigation $9.94 \mathrm{~cm}$ water was used.

\section{Fertilizer application through drip (fertigation)}

The amount of fertilizer to be applied for the individual treatment is calculated out on the basis of the 75 per cent of recommended dose of the fertilizer and was applied in the root zone through the dippers. 12 fertigations were applied through drip.

\section{Micronutrients}

A complete micronutrient mixture namely TRACEL consist of zinc ( $\mathrm{Zn}) 5.0 \%$, copper (Cu) $0.50 \%$, boron (B) $2.5 \%$, molybdenum (Mo) $0.02 \%$, magnesium (Mg) 2.0\%. Spray solution at $2 \%$ concentration was applied. Dissolve $2 \mathrm{~kg}$ in 100 liter of water and about 300 litre of spray solution was used per acre. Three sprays were applied at 2, 3, 5 MAP.

\section{Bunch spray of Sulphate of Potash (SOP)}

SOP at $2 \%$ concentration i.e. $200 \mathrm{~g}$ SOP dissolved in 10 litre of water and added with 2 $\mathrm{ml}$ of wetting agent (soap solution) was sprayed on all fingers of bunches during the opening of last hand (removal of male bud stage). The $2^{\text {nd }}$ spray of SOP was made after 30 days. For 1 acre plantation $4 \mathrm{~kg}$ of SOP was needed for one time spray.

\section{Polyethylene mulching}

Black LDPE mulch of 50 micron was used.

\section{Control}

Recommend dose of fertilizer (RDF) @ $100 \mathrm{~g}$ $\mathrm{N}, 33 \mathrm{~g} \mathrm{P}_{2} \mathrm{O}_{5}$ and $330 \mathrm{~g} \mathrm{~K}_{2} \mathrm{O}$ per plant in the form of Urea, SSP and MOP were applied. Flood irrigation at 15 day intervals were given to the control plot.

Observations were made on the various bunch, hand and finger characters contributing to the 
bunch yield. Harvest Index (on fresh weight basis) was calculated as per the method suggested by Donald (1962).

\begin{tabular}{cc} 
Harvest & Index \\
& Economic yield (bunch weight in $\mathrm{kg}$ ) \\
\hline
\end{tabular}

Total biomass production (total fresh weight per plant in $\mathrm{kg}$ )

\section{Results and Discussion}

\section{Yield attributes in banana}

Significant differences in yield attributes of banana were due to the production of heavier bunch which was the consequence of significant increase in other yield attributing characters. The variation in weight of second hand due to the treatments was found to be highly significant; the highest weight of second hand $(3.65 \mathrm{~kg})$, highest number of hands per bunch (10.95) (Table 1) highest number of finger per hand (25.70), highest weight of finger $(145.91 \mathrm{~g})$, highest length of finger $(22.58 \mathrm{~cm})$ (Table 1), highest finger girth $(13.83 \mathrm{~cm})$, highest volume $(133.41 \mathrm{cc})$ (Table 2), were recorded in all combinations of precision farming components with drip irrigation (80\% ER), fertigation (75\% RDF), micronutrient foliar spray (Commercial formulation 'Tracel' 2\%), bunch spray with potassium (2\%) and black LDPE film mulch $(50 \mu)$ over control (soil application of region specific RDF+ flood irrigation).

The significant improvement in yield attributing characters with fertigation and mulching might be attributed to the improved soil environment with better moisture status and increased availability of plant nutrients which led to better uptake of nutrients by the plant resulting in better vegetative growth and development. The increase in bunch weight and yield through fertigation might be also due to reduced loss of applied fertilisers by leaching and also timely application of required nutrient as per the crop growth stage directly in the root zone of plant and improving the fertilizer-use efficiency (Rolston et al., 1986). These findings were also in conformity with the works of Upadhaya (1995), Salvin (1999) and Khound (2007) in banana. Oubahov and Dafiri (1987) found a positive correlation between potassium and the productivity index (pseudostem circumference) and yield components (number of hands and number of fingers) in banana.

Table.1 Weight of second hand and number of hands per bunch, number of finger per hand, finger weight and length of finger

\begin{tabular}{|c|c|c|c|c|c|}
\hline Treatments & $\begin{array}{c}\text { Weight of } \\
\text { second hand } \\
(\mathrm{kg})\end{array}$ & $\begin{array}{c}\text { Number of } \\
\text { hands per } \\
\text { bunch }\end{array}$ & $\begin{array}{c}\text { Fingers per } \\
\text { hand }\end{array}$ & $\begin{array}{c}\text { Finger } \\
\text { weight (g) }\end{array}$ & $\begin{array}{c}\text { Length of } \\
\text { finger (cm) }\end{array}$ \\
\hline $\mathrm{T}_{1}$ & $3.65^{\mathrm{a}}$ & $10.95^{\mathrm{a}}$ & $25.70^{\mathrm{a}}$ & $145.91^{\mathrm{a}}$ & $22.58^{\mathrm{a}}$ \\
\hline $\mathrm{T}_{2}$ & $3.48^{\mathrm{b}}$ & $10.63^{\mathrm{b}}$ & $24.23^{\mathrm{b}}$ & $139.66^{\mathrm{ab}}$ & $21.65^{\mathrm{b}}$ \\
\hline $\mathrm{T}_{3}$ & $3.32^{\mathrm{c}}$ & $10.29^{\mathrm{c}}$ & $22.65^{\mathrm{c}}$ & $135.22^{\mathrm{abc}}$ & $20.55^{\mathrm{c}}$ \\
\hline $\mathrm{T}_{4}$ & $3.25^{\mathrm{c}}$ & $10.23^{\mathrm{c}}$ & $22.64^{\mathrm{c}}$ & $132.23^{\mathrm{bc}}$ & $20.53^{\mathrm{c}}$ \\
\hline $\mathrm{T}_{5}$ & $2.96^{\mathrm{d}}$ & $9.88^{\mathrm{d}}$ & $19.75^{\mathrm{d}}$ & $127.02^{\mathrm{c}}$ & $19.45^{\mathrm{d}}$ \\
\hline $\mathrm{S}_{\mathbf{E}} \mathbf{E d}_{\mathbf{n}}( \pm)$ & 0.05 & 0.09 & 0.09 & 5.31 & 0.10 \\
\hline $\mathrm{CD}_{0.05}$ & 0.10 & 0.19 & 0.19 & 11.59 & 0.19 \\
\hline
\end{tabular}


Table.2 Girth and volume of finger, bunch weight, yield and harvest index

\begin{tabular}{|c|c|c|c|c|c|}
\hline Treatments & $\begin{array}{c}\text { Girth of finger } \\
(\mathbf{c m})\end{array}$ & $\begin{array}{c}\text { Volume of } \\
\text { finger }(\mathbf{c c})\end{array}$ & $\begin{array}{c}\text { Bunch } \\
\text { weight }(\mathbf{k g})\end{array}$ & $\begin{array}{c}\text { Yield } \\
(\mathrm{t} / \mathrm{ha})\end{array}$ & $\begin{array}{c}\text { Harvest } \\
\text { index }\end{array}$ \\
\hline $\mathrm{T}_{1}$ & $13.83^{\mathrm{a}}$ & $133.41^{\mathrm{a}}$ & $21.68^{\mathrm{a}}$ & $66.91^{\mathrm{a}}$ & 0.32 \\
\hline $\mathrm{T}_{2}$ & $12.88^{\mathrm{b}}$ & $131.40^{\mathrm{a}}$ & $20.53^{\mathrm{b}}$ & $63.36^{\mathrm{b}}$ & 0.31 \\
\hline $\mathrm{T}_{3}$ & $12.37^{\mathrm{c}}$ & $128.88^{\mathrm{b}}$ & $18.63^{\mathrm{c}}$ & $57.50^{\mathrm{c}}$ & 0.31 \\
\hline $\mathrm{T}_{4}$ & $12.36^{\mathrm{c}}$ & $128.60^{\mathrm{b}}$ & $18.58^{\mathrm{c}}$ & $57.35^{\mathrm{c}}$ & 0.31 \\
\hline $\mathrm{T}_{5}$ & $12.13^{\mathrm{d}}$ & $104.73^{\mathrm{c}}$ & $16.58^{\mathrm{d}}$ & $51.17^{\mathrm{d}}$ & 0.30 \\
\hline $\mathrm{S} . \mathrm{Ed}_{0}( \pm)$ & 0.01 & 1.16 & 0.12 & 0.51 & - \\
\hline $\mathrm{CD}_{0.05}$ & 0.02 & 2.52 & 0.26 & 1.12 & NS \\
\hline
\end{tabular}

Increase in length, girth, weight and volume of finger might be attributed to the fact that the production of higher leaf area led to larger photosynthetic area thereby increased production and mobilization of photosynthates in the leaf leading to better filling of the fingers. The favourable influence on carbohydrate metabolism and increased synthesis of protein might have resulted in better $\mathrm{C}$ : $\mathrm{N}$ ratio leading to the more number of fruit production. The present study revealed highest length, girth, weight and volume of finger in treatment $T_{1}$ compared to the lowest in $T_{5}$. This might be attributed to the catalytic function of micronutrients on the physiological functions of the plant specially absorption and utilization of nutrients, cell division and multiplication, higher photosynthetic rate and in translocation of various metabolites etc. which accelerated the growth and development processes.

\section{Yield of banana}

The highest bunch weight ( $21.68 \mathrm{~kg})$, highest yield $(66.91 \mathrm{t} / \mathrm{ha})$ followed by (63.36 t/ha) (Table 2). The significant increase in the yield attributing characters recorded in the present study might be due to application of fertigation which attributed to the improved soil environment with better moisture status and increased availability of plant nutrients which lead to better uptake of moisture and nutrients by the plants resulting in better vegetative growth and development as well as bunch yield. The results were in inconformity with the findings of Raskar (2000) and Kavino et al., (2004). Higher harvest index also gives an indication of higher economic yield. Comparatively high harvest index of 32 per cent were recorded, higher harvest index might be attributed to efficient partitioning of assimilates leading to the development of healthy bunch with higher grade and number of fingers. Present study gets ample support from such studies conducted in a Cavendish group of banana cv. Robusta (Bhattacharyya and Madhava Rao, 1988).

\section{References}

Bhattacharyya, R.K. and Madhava Rao, V.N. (1988). Harvest Index, dry matter production and shoot root ratio of 'Robusta' banana as influenced by soil covers and soil moisture regimes. Paper presented at XXII $^{\text {nd }}$ International Horticulture Congress, ISHS, California, Aug. 11-20, 1986.

Hasan, M.A. and Sirohi, N.P.S. (2006). Drip Irrigation and Fertigation Technology for Improving water Productivity of horticultural crops National Seminar on Technological Options for Improving Water Productivity in Agriculture. JNKVV, Jabalpur. Nov. 15-17.

Kavino, M., Kumar, N., Soorianathasundaram, K. and 
Jeyakumar, P. (2004). Effect of fertigation on the growth and development of first ratoon crop of banana cv. Robusta (AAA) under HDP system. Indian J. Hort.61: 39-41.

Khound, A. (2007). Drip irrigation and fertigation in banana cv. Barjahaji (AAA). M.Sc. (Agri.) Thesis, AAU, Jorhat.

Mulagund, J., Kumar, S., Soorianathasundaram, K. and Porika, $\mathrm{H}$. (2015). Influence of post-shooting sprays of sulphate of potash and certain growth regulators on bunch characters and fruit yield of banana cv. Nendran (French plantain Musa AAB).

Oubahov, A.A. and Dafiri, M. (1987). Banana: nitrogen and potassium nutrition. La nutrition azotee et potassique du bananier. P.H.M. Revue Horticola. 276: 48-49.

Raskar, B.S. (2000). Effect of planting technique and fertigation on growth, yield and quality of banana (Musa sp.). Indian J. Agron.48: 235-237.

Rolston, D.E., Miller, R.J. and Schulbauch, H. (1986). Management principles- fertigation. (in) Trickle Irrigation for Crop Production, Design, Operation and Management. Nakayama and Bucks D A (Eds), Elseuter Amsterdam, p. 317. Salvin, S. (1999). Drip irrigation studies in banana cv. 'Barjahaji' (Musa AAA group, Cavendish subgroup). M.Sc. (Agri.) Thesis, Assam Agricultural University, Jorhat.

Srinivas, K. (1997). Growth, yield and quality of banana in relation to $\mathrm{N}$ - fertigation. Trop. Agric. 74: 260-264.

Srinivas, K., Reddy, B.M.C., Chandra Kumar, S.S., Gowda, T., Raghupati, H.B. and Padma, P. (2001). Growth, yield and nutrient uptake of Robusta banana in relation to $\mathrm{N}$ and $\mathrm{K}$ fertigation. Indian $J$. Hort. 58: 287-93.

Srivastava, R.P. (1964). Effect of microelement on the growth characteristics of banana. Sci. Cult. 30: 352-355.

Upadhyay, D.C. (1995). Drip irrigation in banana has an edge overflow irrigation. Ind. Hort. 40: 13-15.

\section{How to cite this article:}

Utpal Das, R.K. Bhattacharyya and Baruah, K. 2018. Bunch Yield of 'Grand Naine' (AAA) Banana as Influenced by the Varied Components of Precision Farming Systems. Int.J.Curr.Microbiol.App.Sci. 7(05): 501-506. doi: https://doi.org/10.20546/ijcmas.2018.705.063 